\section{Evaluación de la susceptibilidad directa desde hemocultivos positivos utilizando el sistema Vitek 2: comparación de dos protocolos rápidos}

Lorena Porte, Francesca Gattini, Carmen Varela y Thomas Weitzel

Evaluation of antimicrobial susceptibility testing directly from positive blood cultures using the Vitek 2 system: comparison of two rapid protocols

Antimicrobial susceptibility testing using Vitek ${ }^{\circledR} 2$ (bioMérieux) cards inoculated directly from positive blood cultures was compared with the standard method for gramnegative rods. Two different protocols for the inoculum preparation were evaluated. Protocol 2 was faster and easier to perform. Rapid susceptibility testing was accurate and reduced time to results in $24 \mathrm{~h}$.

Key words: Microbial sensitivity tests, blood culture, gram-negative bacteria.

Palabras clave: Pruebas de sensibilidad microbiana, hemocultivos, bacilos gramnegativos.

$\mathrm{E}$ 1 inicio precoz de la terapia antimicrobiana adecuada, reduce la morbimortalidad asociada a la sepsis. Sin embargo, los estudios de susceptibilidad generalmente requieren $48 \mathrm{~h}$ desde que se detecta desarrollo bacteriano en un hemocultivo. La literatura especializada indica que en el caso de los bacilos gramnegativos, es posible obtener la susceptibilidad antimicrobiana $24 \mathrm{~h}$ antes si ésta se realiza directamente a partir de hemocultivos positivos, sin necesidad de esperar el desarrollo bacteriano en cultivo sólido ${ }^{1,2}$. Nuestro objetivo fue evaluar esta metodología utilizando dos protocolos distintos de siembra directa y compararlos con el método tradicional (a partir de una cepa pura).

Método: Entre abril y junio de 2015, se incluyeron hemocultivos positivos (BacT/Alert FA plus ${ }^{\circledR}$, bioMérieux) consecutivos con desarrollo de bacilos gramnegativos, incubados en el equipo BacT/Alert ${ }^{\circledR}$ (bioMérieux). Se excluyeron las muestras duplicadas. Se aplicaron dos protocolos de siembra directa de las tarjetas de susceptibilidad Vitek ${ }^{\circledR} 2$ (Figura 1). El protocolo 1 consistió en inocular $5 \mathrm{ml}$ de sangre de un hemocultivo positivo en un tubo sin aditivos y centrifugar a $600 \mathrm{x}$ g por $10 \mathrm{~min}$. Luego, transferir el sobrenadante a otro tubo y centrifugar a $3.000 \mathrm{x}$ g por $10 \mathrm{~min}$ para crear un pellet de bacterias, resuspenderlo en $2 \mathrm{ml}$ de solución salina $0,45 \%$ y ajustarlo a McFarland 0,5-0,63 ${ }^{1}$. En el protocolo 2, se inocularon $5 \mathrm{ml}$ de sangre de un hemocultivo positivo en un tubo con gel separador (BD Vacutainer, Rutherford, NJ, USA), el que fue centrifugado a $2.000 \mathrm{x}$ g por $10 \mathrm{~min}$. Se eliminó el sobrenadante y se removió el sedimento en la

Laboratorio Clínico, Clínica Alemana de Santiago.

Facultad de Medicina Clínica Alemana/Universidad del Desarrollo.

Recibido: 14 de noviembre de 2016 / Aceptado: 21 de febrero de 2017

Correspondencia a:

Lorena Porte T.

Iporte@alemana.cl superficie de gel con una tórula, para resuspenderlo en $2 \mathrm{ml}$ de solución salina $0,45 \%$ y ajustarlo a McFarland $0,5-0,63^{3}$.

Las suspensiones obtenidas mediante ambos protocolos fueron cargadas en las tarjetas Vitek 2 AST 249, según instrucciones del fabricante. En paralelo, cada botella fue subcultivada en medios sólidos según procedimiento de rutina para identificación (Vitek ${ }^{\circledR}$ MS, bioMérieux) y susceptibilidad antimicrobiana (Vitek ${ }^{\circledR} 2$ ). Los antimicrobianos evaluados fueron amikacina (AKA), cefazolina (CFZ), cefepime (CEF), cefotaxima (CTX), ceftazidima (CAZ), cefuroximo (CXM), ciprofloxacina (CIP), ertapenem (ERT), gentamicina (GEN), imipenem (IMI), meropenem (MEM), piperacilina/tazobactam (PTZ) y cotrimoxazol (SXT).

La concordancia e interpretación fueron analizadas según las normas CUMITECH 31A para verificaciones en que no se compara contra un método estándar":

a. $<5 \%$ de errores mayores (EMA): Susceptibilidad rápida indica resistente (R) y tradicional sensible (S).

b. $\geq 90 \%$ de concordancia categórica $(S, I, R)$ y esencial $(C I M \pm 1$ dilución).

c. $<10 \%$ suma de EMA y errores menores (EME): Susceptibilidad rápida o tradicional indican susceptibilidad intermedia (I).

Hubo desarrollo de 61 bacilos gramnegativos: 40 E. coli, 14 otras enterobacterias (6 Klebsiella spp., 4 Enterobacter spp., 2 Proteus spp., 2 Salmonella sp.). Ambos protocolos de extracción produjeron los mismos resultados, sin embargo, el protocolo 2 resultó más rápido y fácil. Diez cepas fueron $\mathrm{R}$ a cefotaxima. Hubo tres enterobacterias $\mathrm{R}$ a ertapenem, dos $\mathrm{R}$ y una I a imipenem y una $\mathrm{R}$ y dos I a meropenem. Las concor-

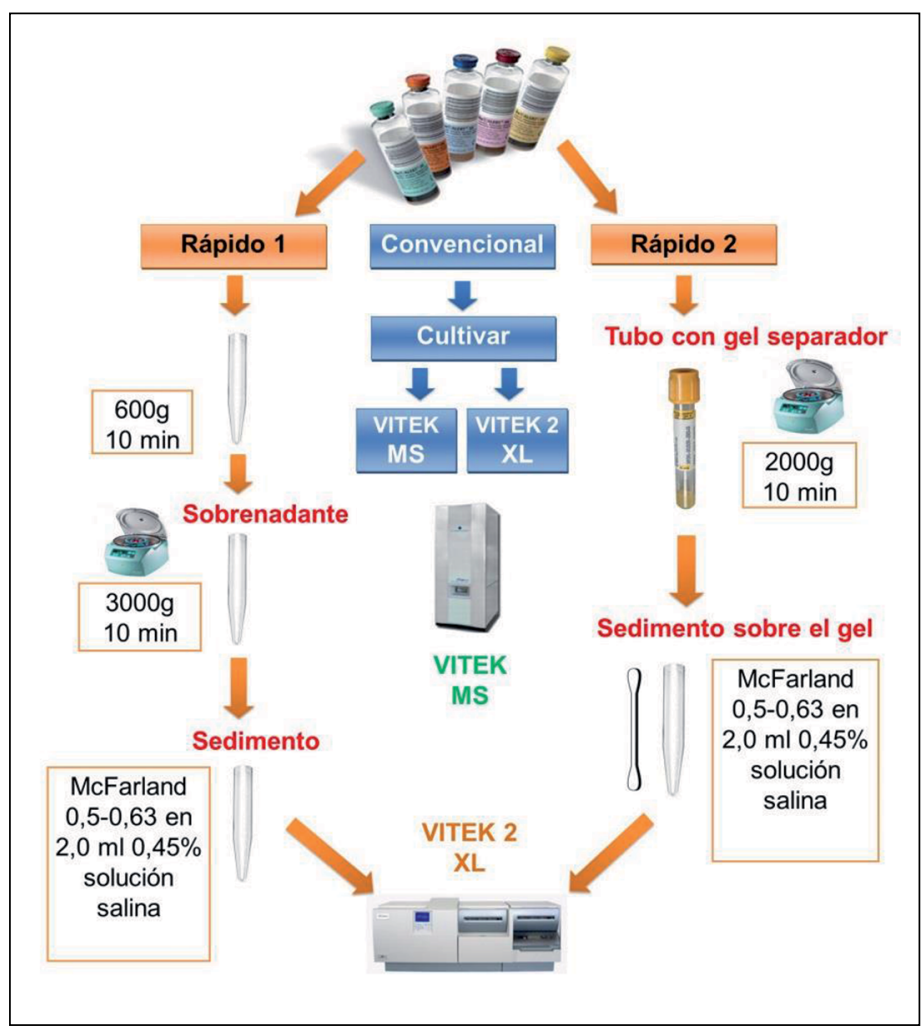

Figura 1. Protocolos de siembra directa hemocultivos en Vitek ${ }^{\circledR} 2$. 


\begin{tabular}{|c|c|c|c|c|c|c|c|c|c|c|c|c|c|c|}
\hline Parámetros & & AKA & CAZ & CFZ & CEF & CTX & CXM & CIP & ERT & GEN & IMI & MEM & PTZ & SXT \\
\hline \multirow{2}{*}{$\begin{array}{l}\text { Concordancia } \\
\text { categórica }\end{array}$} & $\mathrm{n}$ & $61 / 61$ & $61 / 61$ & $45 / 45$ & $60 / 61$ & $54 / 54$ & $49 / 49$ & $60 / 61$ & $53 / 53$ & $61 / 61$ & $61 / 61$ & $61 / 61$ & $61 / 61$ & $54 / 54$ \\
\hline & $\%$ & $100 \%$ & $100 \%$ & $100 \%$ & $98 \%$ & $100 \%$ & $100 \%$ & $98 \%$ & 100 & $100 \%$ & $100 \%$ & $100 \%$ & $100 \%$ & $100 \%$ \\
\hline EMA & $\%$ & $0 \%$ & $0 \%$ & $0 \%$ & $2 \%$ & $0 \%$ & $0 \%$ & $2 \%$ & $0 \%$ & $0 \%$ & $0 \%$ & $0 \%$ & $0 \%$ & $0 \%$ \\
\hline $\mathrm{EMA}+\mathrm{EME}$ & $\%$ & $0 \%$ & $0 \%$ & $0 \%$ & $2 \%$ & $0 \%$ & $0 \%$ & $2 \%$ & $0 \%$ & $0 \%$ & $0 \%$ & $0 \%$ & $0 \%$ & $0 \%$ \\
\hline
\end{tabular}

dancias categórica y esencial entre ambos métodos de susceptibilidad antimicrobiana fueron de $99,7 \%$ y $99,2 \%$ respectivamente. El porcentaje de EMA fue $<5 \%$ y la combinación de EMA y EME fue $<10 \%$ en todos los antimicrobianos (Tabla 1).

La principal limitación de este estudio es el escaso número de aislados incluidos, por lo que los resultados deben interpretarse como preliminares y requieren confirmación con un mayor número de cepas. Sin embargo, esta metodología abre la posibilidad de contar con un resultado de susceptibilidad $24 \mathrm{~h}$ antes que lo habitual, resultando muy útil en caso de pacientes graves que requieren el inicio precoz del antimicrobiano más adecuado.

\section{Resumen}

Se comparó el ensayo de susceptibilidad a los antimicrobianos utilizando las tarjetas Vitek ${ }^{\circledR} 2$ (bioMérieux) inoculadas directamente de hemocultivos positivos con el método estándar para bacilos gramnegativos. Se evaluaron dos protocolos diferentes para la preparación del inóculo. El segundo protocolo fue más rápido y fácil de realizar. Las pruebas de susceptibilidad rápida fueron precisas y redujeron el tiempo de los resultados en $24 \mathrm{~h}$.

\section{Referencias bibliográfcas}

1.- Gherardi G, Angeletti S, Panitti M, Pompilio A, Di Bonaventura G, Crea F, et al. Comparative evaluation of the Vitek-2 Compact and Phoenix systems for rapid identification and antibiotic susceptibility testing directly from blood cultures of Gram-negative and Gram-positive isolates. Diagn Microbiol Infect Dis 2012; 72: 20-31.

2.- Hazelton B, Thomas L C, Olma T, Kok J, O'Sullivan M, Chen S C, et al. Rapid and accurate direct antibiotic susceptibility testing of blood culture broths using MALDI Sepsityper combined with the BD Phoenix automated system. J Med Microbiol 2014; 63: 1590-4.

3.- Kerremans J, Goessens W H, Verbrugh H A, Vos M C. Accuracy of identification and susceptibility results by direct inoculation of Vitek 2 cards from positive BACTEC cultures. Eur J Clin Microbiol Infect Dis 2004; 23 : 892-8.

4.- Clark R B, Lewinsky M A, Loeffelholz M J, Tibbetts. 2009. Cumitech $31 \mathrm{~A}$, verification and validation of procedures in the clinical microbiology laboratory. Coordinating ed., S. E. Sharp. ASM Press, Washington, DC. 